\title{
BRINGING POP-CULTURE INTO CLASSROOM: SPEAKING 3'S GOT TALENT ACTIVITY TO ENHANCE SPEAKING SKILL OF UNIVERSITY STUDENTS
}

\author{
Muhamad Hasbi \\ Institut Agama Islam Negeri Salatiga, Jawa Tengah \\ e-mail: muhamadhasbi.official@gmail.com
}

\begin{abstract}
Following the widespread and growing popularity of English communication across the globe, the implementation of and the research on innovation in language teaching is mushrooming, especially in the teaching of English speaking. This study aims at measuring how far pop-culture themed classroom activity named Speaking 3 's Got Talent gives impacts for students speaking skill improvement at IAIN Salatiga, through an observation of a class in the English Department with a number of students of 30 undertaking Speaking 3 course in the odd-semester of the academic year of 2016/2017. Using a quantitative approach, this research utilizes questionnaire and direct observation for collecting data, and makes use of three methods of data analysis namely questionnaire scale-analysis, CEFR (The Common European Framework) speaking grid, and teacher's made rubric for speaking for assessment which pinpoint three key measured variables namely students' attitude toward the activity, teacher's assessment toward students' performance referring to both CEFR and teacher's made rubric. This research finds that students had positive (excellent and very good) attitude towards the time, English, avatar, expertise and assessment variables of the activity and viewed that it is effective in downgrading their degree of stage fright; secondly, students obtain excellent and very good assessment in both the CEFR and teacher's made rubric model. The three methods of measurements implied its affectivity in enhancing university students' speaking skill and both student and teacher assessment recommend this activity to be applied in English classrooms.
\end{abstract}

Keywords: speaking skill, pop-cultural activity, attitude, stage fright, assessment

\section{INTRODUCTION}

$\mathrm{E}$ nglish may have been defeated by Chinese in terms of the number of speakers, but it continues to be the most widely spread. The current study in 2014 found that out of 6000 people in Brazil, China, Germany, Indonesia, Poland, South Korea, USA, Mexico, Turkey, Russia, India, and Japan who were taken as the research sample agreed that English is the most valuable second language in the world, followed by Spanish, German, Chinese Mandarin, and French (Morar Consulting and Pearson English, 2014). Language education has always given this phenomenon special attention that nowadays education system in most countries now places English as the most-prioritized foreign language to be learned at their schools since early years. This trend gives rise to a new concern on the innovation of English language 
teaching which aims at applying up-todated, well-perceived, and engaging materials, methods and approaches, activity, up to assessment in order to achieve the expected goals of English language learning.

Another interesting fact is, though speaking is seen as one of the most difficult among the four English skills, another result of the same study as above highlighted that speaking is seen as the most-interested to be mastered, assuming the higher demands of international communication skills following the everdeveloping advancement of the technology across the globe. This can be a good start propose an idea that the teaching of speaking skill at our schools and universities plays an ultimate role in realizing this demand and thus must be presented efficiently at classroom.

Educators and language researchers actually have since long contributed themselves. If we scan through the recent 15 years, a huge number of innovations in teaching speaking have been being implemented across the globe in order to present the most effective methods and approaches to satisfy the outcome of teaching learning process, say the initiation of implementing the supplementary activity called chat-rooms (Hamano-Bunce, 2011) and the primary activity called small-talk (Hunter, 2012), to name a few.

On top of the rank, Communicative Language Teaching (CLT) is considered the most effective method of teaching speaking applied in ESL and EFL countries which is confirmed by a research which revealed the theory and practices of CLT pose as a reply to the previous pros and cons of CLT applicability across the world (Hiep, 2007). His findings suggested adapting CLT instead of adopting it. Several years earlier, in China (Liao, 2004), after careful trials the central government determined CLT as the only English teaching approach and the others are in no possibility to be used. In India (Gupta, 2004), CLT was practiced but hardly applied at first due to teachers' poor understanding of CLT and no demands from the environment and students. When their paradigm shifted, it is now highly prospected even though not placed as the primary approach in teaching. More recently, Griffiths (2011) in her article surveying ESL teachers issued whether traditional approaches, i.e., Grammar Translation Methods (GTM) and Audio-Lingual Method (ALM) and communicative approach are dichotomous or not and resulted that they are best complementary, going hand in hand in real teaching application.

\section{Speaking3's Got Talent}

The idea of this activity was initiated by researcher's random observation when handling speaking class where students were often not engaged in the classroom activity using conventional methods. This situation triggers the thought of bringing a popular culture familiar to young generation which offers entertainment to some extent but still maintains the goals of the speaking class which finally falls into Speaking 3's Got Talent activity. This activity is an adaptation of a popular TV show namely America's Got Talent which has been adopted in our country into Indonesia Mencari Bakat, in which students would have to present one of their talents at class but using English as their means of communication. As it might sound, this activity channels through the principles of CLT. Again, the finalization of the format of this activity is through an adaptation process, and not an adoption as suggested by Hiep (2007) to capture the expected target of the activity and to avoid applying unnecessary process. 
The final adapted format follows the following steps: 1) students were given an introductory session of the concept of performance and assessment in the Speaking 3 's Got Talent Activity a week before the activity begins, 2) students made their performance based on the schedule implementing the efficiency of time (an proximate duration of 12 to 15 minutes), avatar (dressing up in costume themed with the kind of their performed talent), English (the communicational aspect of their English in use), and expertise (the degree to which the student are able to prove their mastery of the skill through demonstration and so on) as discussed beforehand, 3) teacher scored the performance and gives students feedback on the fours aspects of assessment.

As can be seen above, this format of speaking puts an emphasis on the aspect of performance, which is in line with the most recent function speaking redefined by Jack C. Richards (2006) namely talk as performance, to add the other two functions much earlier introduced by Brown and Yule (1983) namely talk as interaction and talk as transaction. Meanwhile the interactional function of speaking serves to establish and maintain social relations, and the transactional function focuses on the exchange of information, the latest function expands its coverage such as using an appropriate format, presenting information in an appropriate sequence, maintaining audience engagement, creating an effect on the audience, using appropriate vocabulary, and using an appropriate opening and closing (Richards, 2006), and monitoring or listening process to keep tracks of the information transfers between student as the speaker and the students as the audience (Sayer, 2005). Therefore, nondiscourse aspects such as avatar, time management, as well as the expertise of the talent are in here equally considered as the assessment variables as the language aspect.

In line with the background of the study and the introduction to this activity, this research would like to determine whether Speaking 3's Got Talent is able to enhance speaking skill and whether students' attitude toward the activity and teacher assessment towards students' performance are mutual and recommend for upcoming application in the English classrooms.

\section{Learner's Attitude}

According to Gardner (1985) attitude is an evaluative reaction to some referent or attitude object, inferred on the basis of the individual's beliefs or opinions about the referent. In the context of this research, learner's attitude refers to students' evaluative reaction to the Speaking 3's Got Talent activity being implemented which take account their opinion towards all aspects of it through their real experience. This attitude is then the one which drives their motivation and their overall process in undergoing the activity from their preparation process, their performance and how they assess their own performance as it was later stated by Gardner, "Attitude is thus linked to a person's values and beliefs and promotes or discourages the choices made in all realms of activity, whether academic or informal". Attitude is also defined as a disposition or tendency to respond positively or negatively towards a certain thing such as an idea, object, person, or situation. Students have positive or negative attitudes towards the language they want to learn or the people who speak it. Studies have shown that attitude is one of the key factors for success in language learning (Alhmali, 2007; Ghazali et al., 2009). 
Attitude is crucial in bringing motivation and achievement in learning process, and in this context, justifies the overall quality seen as they do the activity. As Reid (2003) declared, "Attitudes are important to us because they cannot be neatly separated from study." Attitude is therefore an essential factor influencing language performance. A positive attitude often leads learners to use a variety of learning strategies that can facilitate skill development in language learning. A positive attitude leads to a greater overall effort on the part of language learners and typically results in greater success in terms of overall language proficiency and competence in specific language skills such as listening, speaking, reading and writing. In line with Gardner's (1985) that a positive attitude helps learners maintain their language skills after classroom instruction is over, the Speaking 3's Got Talent activity is expected to give impacts on students' improving speaking skill even after the activity is done.

\section{Stage Fright}

Speaking in front of public such as at class using foreign language can be dilemmatic for language learners. Students can experience many unlikeable symptoms such as nervousness, numbness, speechless, etc. This fear or anxiety of that people experience when anticipating or engaging in public is called 'stage fright' (McCrosky, 1976). In the other words, it is the fear before or during a performance, the fear of not being able to deal with the increased stress during a performance (Van der Loo, 2008). Stage fright, which was earlier called as 'speech fright' or 'speech anxiety', are now known by several different terms such as fear of public speaking, performance anxiety, and communication apprehension (Mak, 2010).

Almost all foreign language learners have gone through such embarrassing and depressing experience of speaking English at class. The good news is that public speaking can be learned. And what's left for language teachers and researchers is to discover innovative ways in helping students deal with that, and this is why researcher adds downgrading stage fear as one of the concern of the research. As one of the most suggestible ways to reduce it is by revising the negative perceptions, thoughts and beliefs you have related to public speaking or performing (Esposito, 2012), researcher are convinced that measuring students' attitude or perception toward the activity is a must.

\section{RESEARCH METHOD}

This study keeps track of the whole process experienced by 30 students in the English Department at IAIN Salatiga who took part in the Speaking 3's Got Talent activity. Being based on testing of the theory composed of variables, measured with the numbers and analyzed with statistical procedures, in order to determine whether the predictive generalizations of the theory hold true (Creswel, in Hasbi, 2013: 3), the researcher uses descriptive method with quantitative approach.

The first instrument used to gather the data is questionnaire. For the first implementation of a new activity such as Speaking 3's Got Talent, measuring how students react to the activity is absolutely an integral part, and the employment of questionnaire gives measurable and valid depiction of their real response to it. The questionnaire consists of 21 statements investigating learner's attitude towards the key four elements in the activity, i.e.., time, English, expertise, avatar (represented in 
3 statements for each), the assessment system, its impact for downgrading their stage-fright (represented in 5 statements), and whether the activity is recommendable to be implemented henceforth. The questionnaire used five optional answers style of Likert scale, i.e., strongly agree, agree, neutral, disagree, and strongly disagree which earns a score of 5 to 1 orderly. Questionnaire scale-analysis works for extracting the final score of each criterion using the following formula:

$$
\mathrm{TSx}=\frac{\mathrm{N}_{\mathrm{SA}}+\mathrm{N}_{\mathrm{A}}+\mathrm{N}_{\mathrm{N}}+\mathrm{N}_{\mathrm{D}}+\mathrm{N}_{\mathrm{SD}}}{\mathrm{N}_{\mathrm{S}}}
$$

\author{
TSx: total score of a criterion \\ $\mathrm{x} \quad$ : a criterion (time, English, etc) \\ $\mathrm{N}_{\mathrm{SA}}$ : total occurrence of strongly agree \\ $\mathrm{N}_{\mathrm{A}}$ : total occurrence of agree \\ $\mathrm{N}_{\mathrm{N}}$ : total occurrence of neutral \\ $\mathrm{N}_{\mathrm{D}}$ : total occurrence of disagree \\ $\mathrm{N}_{\mathrm{SD}}$ : total occurrence of strongly \\ $\mathrm{N}_{\mathrm{S}}$ : total number of students
}

Note: The total score (TSx) will be in a scale of 5 where $0-1$ indicates bad attitude, 1,1-2 indicates fair attitude, 2,1-3 indicates good attitude, 3,1-4 indicates very good attitude, and 4,1-5 indicates of students toward the activity.

To record the statistical analysis of the speaking skill output, two kinds of rubric were in use; one being the widely used CEFR (The Common European Framework) grid for speaking skill, and another being teacher's made rubric. The CEFR grid measures students' level of oral skill achievement including the 5 criteria of speaking skills namely range (the extent of a delivered topic), accuracy (accurate grammatical use), fluency (smooth flow of speech), interaction (oral engagement between speakers), and coherence (chronological flow of idea). The CEFR categorizes the level of each aspect into 6 categories namely $\mathrm{C} 2$ (Upper advance), $\mathrm{C} 1$ (Advance), B2 (Upper intermediate), B1 (Intermediate), A2, (Upper beginner) and A1 (Beginner); the higher their competencies in each criterion, the upper their level places from A1 to C2 (North, 2014: 169). For this research, researcher observes the performances of the students and note down the level category of each oral skill criterion right after they perform.
The teacher's made rubric measures the achieved expectation of the speaking performance which include the aspects of time (being able to speak effectively for 10 to 15 minutes), English (constantly using English while presenting), expertise (being able to convince their mastery of the talent), and avatar (dressing-up in thematic attire and making use of supporting properties) which was socialized to the students prior to the performance day so that they already know what to optimize when performing. In gathering the data, researcher observes the performances of the students and note down the level category of each oral skill criterion right after they perform. The actual scoring system for the class uses only this teacher's made rubric as it is adjusted right to the targeted goals of the activity, while the CEFR grid is occupied only for the research purpose to find out if at the same time the product also satisfied standardized assessment measurement.

In short, the questionnaire reflects students' perspective concerning more 
on their attitude toward the activity and both CEFR and teacher's made rubric reflects the teacher's perspective concerning more on his assessment to the students' performance. In testing the applicability of an innovative activity like this, it is very essential to elicit evidence from both students and teacher to ascertain the validity of the research results viewed equally from both sides so there will be no more room for a debate.

\section{DISCUSSION}

The data presentation and its discussion is carried out in order, from the questionnaire, the CEFR oral assessment grid, then the teacher's made rubric as follows:

\section{Questionnaire}

\begin{tabular}{|c|c|c|c|c|c|c|c|c|}
\hline \multirow[b]{2}{*}{ No. } & \multirow{2}{*}{$\begin{array}{c}\text { Measured } \\
\text { variables }\end{array}$} & \multicolumn{5}{|c|}{ Frequency of occurrence } & \multirow{2}{*}{\multicolumn{2}{|c|}{ Final average score }} \\
\hline & & $\begin{array}{c}\text { strongly } \\
\text { agree }\end{array}$ & agree & neutral & disagree & $\begin{array}{l}\text { strongly } \\
\text { disagree }\end{array}$ & & \\
\hline 1. & time & $24 / 90$ & $62 / 90$ & $4 / 90$ & - & - & 4.21 & \multirow{7}{*}{$\begin{array}{l}\text { level of } \\
\text { attitude: } \\
4,1-5: \\
\text { excellent } \\
3,1-4: \\
\text { very good } \\
2,1-3 \text { : } \\
\text { good } \\
1,1-2 \text { : fair } \\
0-1 \text { : bad }\end{array}$} \\
\hline 2. & English & $37 / 90$ & $44 / 90$ & $9 / 90$ & - & - & 4.28 & \\
\hline 3. & expertise & $26 / 90$ & $42 / 90$ & $21 / 90$ & $1 / 90$ & - & 4.07 & \\
\hline 4. & avatar & $26 / 90$ & $52 / 90$ & $12 / 90$ & - & - & 4.14 & \\
\hline 5. & assessment & $30 / 90$ & $55 / 90$ & $5 / 90$ & - & - & 4.27 & \\
\hline 6. & $\begin{array}{l}\text { stage fright } \\
\text { downgrade }\end{array}$ & $37 / 150$ & $78 / 150$ & $35 / 150$ & - & - & 4.01 & \\
\hline 7. & $\begin{array}{l}\text { recommendability } \\
\text { for future } \\
\text { application }\end{array}$ & $15 / 30$ & $14 / 30$ & $1 / 30$ & - & - & 4.47 & \\
\hline
\end{tabular}

Figure 1. The recap of Questionnaire data input

The above table depicts the final analysis of the questionnaire distributed to the 30 subject students. The result shows that students in average has excellent attitude in the variable of time (4.21), English (4.28), avatar (4.14), and assessment (4.27). To be more specific, it is evident that this activity indeed trains students in handling time management, improving their speaking skill, in carrying out performance with supporting attire or instruments, and in adjusting their performance to meet with the expected scoring measurement. Students also agreed that the activity helps them discover or improve their talent (4.07) and downgrade the level of stage fright such as discomfort, nervousness, unconfidence, getting lost, and tense (4.01) in which both mirror a very good attitude. In a more serious note, this activity receives the fantastic support from most of them (4.47) to be applied in the Speaking classes for upcoming generation.

It is as much as interesting too to take a closer look at grid of the frequency of occurrence of students' answers where none has voted any strongly disagree response, and only one voted disagree which is a very strong validation to the efficiency of the activity. As marked in gray, almost all of the variables were poured majorly with agree responses, while in terms of activity's recommendability for future application were dominated with the answer strongly disagree with only one student said neutral. It is not too much then that from students' perspective, a 
classroom activity like this deserves its existence to be present longer at English classrooms.

\section{The CEFR Grid (Oral Skill)}

The following figure determines the overall students' oral assessment referring to the standardized CEFR grid which as can be seen confirms that Speaking S's Got Talent gives impacts but distinctly to each variable.

\begin{tabular}{|c|c|c|c|c|c|c|c|c|}
\hline \multirow{3}{*}{ No. } & \multirow{3}{*}{$\begin{array}{c}\text { Measured } \\
\text { variables }\end{array}$} & \multicolumn{6}{|c|}{ Frequency of occurrence } & \multirow{3}{*}{ Total } \\
\hline & & \multicolumn{2}{|c|}{ Advance } & \multicolumn{2}{|c|}{ Intermediate } & \multicolumn{2}{|c|}{ Beginner } & \\
\hline & & Level C2 & Level C1 & Level B2 & Level B1 & Level A2 & Level A1 & \\
\hline \multirow[b]{2}{*}{1.} & \multirow{2}{*}{ range } & 5 & 13 & 7 & 3 & 2 & - & \multirow{2}{*}{30} \\
\hline & & \multicolumn{2}{|c|}{18} & \multicolumn{2}{|c|}{10} & \multicolumn{2}{|c|}{2} & \\
\hline \multirow[b]{2}{*}{2.} & \multirow[b]{2}{*}{ accuracy } & 2 & 5 & 6 & 8 & 10 & 2 & \multirow[b]{2}{*}{30} \\
\hline & & \multicolumn{2}{|c|}{7} & \multicolumn{2}{|c|}{12} & \multicolumn{2}{|c|}{13} & \\
\hline \multirow{2}{*}{3.} & \multirow{2}{*}{ fluency } & 3 & 5 & 7 & 6 & 8 & 1 & \multirow{2}{*}{30} \\
\hline & & \multicolumn{2}{|c|}{8} & \multicolumn{2}{|c|}{13} & \multicolumn{2}{|c|}{9} & \\
\hline \multirow{2}{*}{4.} & \multirow{2}{*}{ interaction } & 6 & 14 & 4 & 3 & 3 & - & \multirow{2}{*}{30} \\
\hline & & & & & 7 & & & \\
\hline \multirow[b]{2}{*}{5.} & \multirow{2}{*}{ coherence } & 4 & 18 & 4 & 3 & 1 & - & \multirow{2}{*}{30} \\
\hline & & \multicolumn{2}{|c|}{22} & \multicolumn{2}{|c|}{7} & \multicolumn{2}{|c|}{1} & \\
\hline
\end{tabular}

Figure 2. The recap of the CEFR Oral Skill assessment

Among the five variables, the activity gives most impact to coherence, followed by interaction and range which place students having advance level of coherence, interaction, and range. Having 22 students topped the level confirms that the activity is effective in helping students deliver their speech in more organized and chronological order which also helps the audience follow the flow of speakers' idea smoothly. Its influence to their interaction process is extremely high too; having 20 students reaching advance level followed by 7 students at the intermediate makes no more debate that more talking happened two ways in the class which triggered more engagement and avoided the feeling of boredom. With 18 numbers of students at the advance plus 10 at the intermediate level, it is not arguable that this activity is also successful at training them touch wider area when talking.

However, its impact on helping them with fluency and especially accuracy is not that satisfying where the majority of them reach only intermediate for fluency and even worse for accuracy at the beginner. Cross-referencing with researcher's classroom observation, though a little dissatisfying this graph seems logical and not at its worst because the ultimate goal of introducing this activity is more concerned to develop the communication over the grammatical accuracy. And we cannot forget the fact that it needs time for foreign language speaker to be able to balance the preciseness of communication with the grammatical accuracy. Overall, the final result of students' performance referring to the CEFR grid is very impressive and this is strongly in line with the result of the questionnaire analysis which is ended with a recommendation for future application at English classrooms. 


\section{The teacher's made rubric}

\begin{tabular}{|l|l|c|c|c|c|c|c|c|c|c|c|c|}
\hline \multirow{2}{*}{ No. } & Measured & \multicolumn{10}{|c|}{ Frequency of score occurrence } & \multirow{2}{*}{ Total } \\
\cline { 3 - 15 } & variables & $(1)$ & $(2)$ & $(3)$ & $(4)$ & $(5)$ & $(6)$ & $(7)$ & $(8)$ & $(9)$ & $(10)$ & \\
\hline 1. & time & - & - & - & - & 2 & 1 & 4 & 9 & 11 & 5 & 30 \\
\hline 2. & English & - & - & - & - & - & 2 & 2 & 3 & 14 & 9 & 30 \\
\hline 3. & expertise & - & - & - & - & - & - & 2 & 11 & 9 & 8 & 30 \\
\hline 4. & avatar & - & - & - & - & - & 3 & 4 & 10 & 8 & 5 & 30 \\
\hline $\begin{array}{ll}\text { Note: } \\
\text { score of 1-2: poor } \\
\text { excellent }\end{array}$
\end{tabular}

Figure 3. The recap of the teacher's made rubric assessment

As can be seen above, the figure displays a very satisfactory result in all measured variables. The majority of the students' performance falls under excellent level (score of 9 plus 10) vividly in time, English, expertise variables, and very good level (score of 7 plus 8) in the avatar variable. The grey mark identifies the level where majority of the students gains their achievement which is very impressive. Besides its supporting concept, the teacher's feedback session right after students' performance, like the commenting session seen in the reality show America's Got Talent, might play an important role too, because at the moment teacher overview the plus and minus points of the performances followed by several suggestions that can be learned not only by the performing students but more importantly by the coming performers, so they learn not to make mistakes experienced by the previous performers and make improvements on the targeted aspects.

\section{CONCLUSION}

The analytical result of the Speaking 3's Got Talent activity using three barometers including students' attitude gathered through questionnaire, teacher's evaluation using the CEFR oral assessment grid, and teacher's evaluation using teacher's made rubric shows a very satisfying result. It is evident that students had excellent attitude towards time, English, avatar, and assessment variables; students had very good attitude towards expertise and avatar variables; and students recommended this activity to be in use in the upcoming years. The CEFR oral assessment confirms its affectivity in maximizing the range, interaction, and coherence of the majority into advance level; their fluency into intermediate level; and their accuracy into beginner level. The teacher's made rubric confirms its affectivity in elevating their time and English skill into excellent level, while expertise and avatar reach very good level.

From the research finding, researcher strongly recommends for this activity to be conducted in the English classrooms as it is effective in enhancing English speaking skill and downgrading stage fright. Future research on this activity is suggestible to challenge its degree of applicability across major and institution and if it might happen, it would be insightful idea to conduct comparable studies with the similar or even very distinctive methods. Adaptation of this method is indeed welcomed, especially the one targeted on accuracy and fluency development, in which the present format of Speaking 3's Got Talent is yet to fulfill the expected goal. In conclusion, innovation in language teaching must always be 
encouraged, and bringing pop-cultural activities like this into classroom can be one of the effective alternatives, because apart from its familiarity to young and

\section{REFERENCE}

Alhmali, J. (2007). Student attitudes in the context of the curriculum in Libyan education in middle and high schools (PhD Thesis). Scotland: The University of Glasgow. Retrieved from http://theses.gla.ac.uk/61/ on November 3, 2016.

Brown, G. \& Yule, G. 1983. Teaching the spoken language. Cambridge, United Kingdom: Cambridge University Press.

Esposito, Janet M. 2012. Getting Over Stage Fright: Becoming an Effective Public Speaker. Shyness is Nice. Missouri: Love Your Life Publishing, Inc.

Gardner, R. C. (1985). Social psychology and second language learning: The role of attitudes and motivation. London: Edward Arnold Publishers.

Ghazali, S. Setia, R., Muthusamy, C. \& Jusoff, K. (2009). ESL students attitude towards texts and teaching methods used in literature classes. English language teaching., 2, 51.

Griffiths, Carol. 2011. The traditional/ communicative dichotomy (ELT Journal volume 65/2). The United Kingdom: Oxford University Press.

Gupta, Deepti. 2004. CLT in India: context and methodology come together (ELT Journal volume 58/2). United Kingdom: Oxford University Press. adult learners, it offers a lot more benefits as long as its application is taken care of and well-prepared.

Hamano-Bunce, Douglas. 2011. Talk or chat? Chat-room and spoken interaction in a language classroom (ELT Journal volume 65/3). The United Kingdom: Oxford University Press.

Hasbi, Muhamad. 2013. The Attitudes of Students from ESL and EFL Countries to English (Register Journal volume 6 No.1). Salatiga: STAIN Salatiga.

Hiep, Pham Hoa. 2007. Communicative Language Teaching: unity within diversity (ELT Journal volume 61/2). The United Kingdom: Oxford University Press.

Hunter, James. 2012. 'Small Talk': Developing Fluency, Accuracy, and Complexity in Speaking (ELT Journal volume 66/1). The United Kingdom: Oxford University Press.

Liao, Xiaoqing. 2004. The need for CLT in China (ELT Journal volume 58/2). The United Kingdom: Oxford University Press.

Loo, M. Van Der. 2008. Podiumangst: de schaamte voorbij. Effectmeting van taakconcentratietraining op podiumangst bij conservatoriumstudenten (Translation). The Netherlands Open University: Faculty of Psychology.

Mak, Peter. 2010. Peak performance and Reducing Stage Fright. The Netherlands: Research Group 
Lifelong Learning in Music \& The Arts.

McCroskey, James C. 1976. The Problem of Communication Apprehension in the Classroom (FSC Journal, Vo. 4, No. 2). Florida: Florida Southern College.

Morar Consulting and Pearson English. 2014. American English vs British English. Online publication: https://www.english.com/blog/insp iredtolearn-american-english-vsbritish-english (retrieved on November 3, 2016).

North. B. 2014. The CEFR in Practice. The United Kingdom: Cambridge University Press.
Reid, K. 2003. An evaluation of an outof-school-project in South Wales. Mentoring and Tutoring. Abingdon: Routledge.

Richards, J. C. 2006. Communicative language teaching today. New York: Cambridge University Press.

Sayer, Peter. 2005. An intensive approach to building conversational skills (ELT Journal volume 59/1). The United Kingdom: Oxford University Press.

The Council of Europe. 2012. The Common European Framework (CEFR). London: Cambridge University Press. 